\title{
Pembelajaran Berbasis HOTS sebagai Bekal Generasi Abad 21 di Masa Pandemi Nora Dwijayanti
}

Universitas Sebelas Maret noradwi@student.uns.ac.id

\section{Article History}

received 30/4/2021

\begin{abstract}
21st century skills are divided into four or we are familiar with the term $4 C$ (Critical Thinking and Problem Solving, Creative Thinking and Innovation, Collaboration, Communicatin). Critical thinking skills can be implemented with HOTS (High Order Thinking Skill) based learning. HOTS-based learning can be used as an alternative to face the demands of the 21st century. HOTS learning can still be applied during this pandemic by online/virtual face-to-face. Teachers can take advantage of various digital applications that can be used to support the teaching and learning process. Thus, teachers need to increase creativity and innovation so that students stay focused on understanding the material presented. This situation can be used as a motivation by the teacher to package the presentation of material as attractive as possible and innovative, and creative.
\end{abstract}

Keywords: 21st century skills, HOTS-Based Learning, Pandemic

\section{Abstrak}

Keterampilan abad 21 dibedakan menjadi empat atau kita kenal dengan istilah 4C (Critical Thinking and Problem Solving, Creative Thinking and Innovation, Collaboration, Communicatin). Keterampilan berpikir kritis dapat diimplementasikan dengan pembelajaran berbasis HOTS (High Order Thinking Skill). Pembelajaran berbasis HOTS dapat dijadikan sebagai alternatif untuk menghadapi tuntutan abad ke 21. Pembelajaran HOTS tetap dapat diterapkan di masa pandemi ini dengan daring/tatap maya. Guru dapat memanfaatkan berbagai aplikasi digital yang dapat diguakan sebagai penunjang proses belajar mengajar. Sehingga, guru perlu meningkatkan kreativitas dan inovasi agar anak didik tetap fokus memahami materi yang disampaikan. Keadaan ini dapat dijadikan motivasi oleh guru untuk mengemas sajian materi semenarik mungkin dan inovatif, serta kreatif.

Kata kunci: Keterampilan Abad 21, Pembelajaran Berbasis HOTS, Pandemi 


\section{PENDAHULUAN}

Perkembangan ilmu pengetahuan di Indonesia melaju dengan pesat di berbagai bidang, termasuk diantaranya yakni bidang pendidikan. Kemajuan tersebut dapat dilihat dari pemanfaatan ICT di berbagai tingkatan sekolah, baik sekolah tingkat dasar sampai perguruan tinggi. Wawasan informasi dapat kita akses dengan sangat mudah dan cepat oleh siapapun dari berbagai belahan dunia. Jaringan komunikasi antar individu dapat dilakukan dengan murah, mudah, kapan saja dan di mana saja tanpa harus saling bertemu tatap muka. Keadaan inilah yang dapat kita katakan sebagai generasi abad 21. Individu dituntut untuk menjadi pribadi yang mandiri, berkemampuan, dan berkemuajuan sehingga dapat mewujudkan cita-cita bangsa (Supardi, 2015). Perkembangan tersebut berpengaruh terhadap tatanan di dunia pendidikan, terutama bagi guru dan peserta didik. Guru dituntut untuk mahir dalam menggunakan perangkat digital agar pembelajaran menjadi inovatif dan kreatif. Peserta didik juga diharapkan dapat mengimbangi kemajuan tersebut dengan adanya fasilitas seperti laptop, HP, komputer, dll. Hal ini searah dengan pendapat Eggen \& Kauchack (2012) yang menyatakan bahwa standar bagi guru dan peserta didik untuk sekolah abad digital atau abad 21 berkaitan dengan penggunaan teknologi dalam pembelajaran. Guru sebaiknya dapat bertindak sebagai fasilitator yang senantiasa mengajarkan pendidikan berbasis digital kepada anak didik.

Keterampilan abad 21 dibedakan menjadi empat atau kita kenal dengan istilah 4C (Critical Thinking and Problem Solving, Creative Thinking and Innovation, Collaboration, Communicatin). Nasional Education Asociation (NEA) merekomendasi menyebutnya dengan Four Cs (Ferdinandus \& Desak, 2018). Critical Thinking atau dapat kita kenal dengan berpikir kritis yakni pola berpikir yang memiliki sifat konvergen, sedangkan Creative Thinking atau berpikir kreatif lebih bersifat divergen. Proses yang dilakukan untuk mengolah suatu informasi dari berbagai sudut pandang untuk dihasilkan suatu kesimpulan dinamakan dengan pola pikir konvergen. Sedangkan suatu informasi yang dikembangkan menjadi ide, konsep, sudut pandang, dan menghasilkan suatu produk dinamakan dengan pola pikir konvergen (Sani, 2019). Keterampilan berpikir kritis dapat diimplementasikan dengan pembelajaran berbasis HOTS (High Order Thinking Skill). Pembelajaran berbasis HOTS dapat dijadikan sebagai alternatif untuk menghadapi tuntutan abad ke 21

Pembelajaran berbasis HOTS merupakan suatu program yang dicanangkan oleh Kementerian Pendidikan dan Kebudayaan (Kemdikbud) yang pada tahun 2018 telah terintegrasi Penguatan Pendidikan Karakter (PPK) dan pembelajaran berorientasi pada Keterampilan Berpikir Tingkat Tinggi atau Higher Order Thinking Skill (HOTS). Peserta didik dilatih untuk menyelesaikan suatu permasalahan dengan menyertakan kesimpulan. Aktivitas peserta didik dalam pembelajaran berbasis HOTS menurut Sani (2019) adalah aktif dalam berpikir, memformulasikan masalah, mengkaji permasalahan kompleks, berpikir divergen dan mengembangkan ide, mencari informasi dari berbagai sumber, berpikir kritis dan menyelesaikan masalah secara kreatif serta berpikir analitik, evaluatif, dan membuat keputusan. Oleh karena itu, guru senantiasa melatih anak didik untuk dapat berpikir tingkat tinggi.

Pembelajaran HOTS tetap dapat diterapkan di masa pandemi ini dengan daring/tatap maya. Guru dapat memanfaatkan berbagai aplikasi digital yang dapat diguakan sebagai penunjang proses belajar mengajar. Sehingga, guru perlu meningkatkan kreativitas dan inovasi agar anak didik tetap fokus memahami materi yang disampaikan. Semenjak dikeluarkannya SE Mendikbud perihal pembelajaran secara daring dan bekerja dari rumah, pembelajaran yang awalnya dilakukan secara konvensional oleh setiap satuan pendidikan perlahan digantikan dengan adanya aplikasi berbasis online sehingga guru tidak perlu bertatap muka dengan siswa (Trisiana, A., 2020). Adanya aplikasi digital yang beragam menjadikan individu dapat terbantu menyelesaikan suatu permasalahan dengan berpikir kritis dengan cara 
mencari berbagai informasi pada berbagai platform digital yang kompleks. Pada saat pembelajaran, guru diharapkan terampil menggunakan media pembelajaran/ alat peraga baik yang konvensional maupun digital secara tepat. Hasil riset BAVA (British Audio Visua Aids) memaparkan bahwa hasil pembelajaran yang tidak menggunakan media hanya $13 \%$ dari keseluruhan materi yang telah diberikan. Dengan menggunakan media pembelajaran, perolehan bahan ajar yang diserap dapat ditingkatkan hingga 86\%. (Rusman, 2013). Keadaan ini dapat dijadikan motivasi oleh guru untuk mengemas sajian materi semenarik mungkin dan inovatif, serta kreatif.

\section{A. Keterampilan Abad 21}

\section{HASIL DAN PEMBAHASAN}

Keterampilan pada abad 21 dikenal dengan istilah $4 \mathrm{C}$ yang dapat dipaparkan sebagai berikut:

1. Critical Thinking

Menurut Halpern (2014) berpikir kritis yakni suatu keterampilan yang dapat dilakukan untuk menyelesaikan permasalahan yang kompleks (problem solving) dan pengambilan suatu keputusan. Teori Halpern mencakup tentang ingatan, pemikiran dan bahasa, menalar secara deduktif, analisis argument, menguji hipotesis, kemiripan dan ketidakpastian, pengambilan keputusan, penyelesaian masalah, dan berpikir kreatif.

2. Creative Thinking

Keterampilan berpikir kreatif yakni suatu keterampilan dimana individu dapat menggasilkan suatu gagasan, ide, konsep, atau produk yang berbeda dengan yang sudah ada karena disesuaikan dengan kreativitas sendiri (Sani, 2019). Oleh karena itu, sesorang dapat dikatakan kreatif jika dapat membuat atau merangkai sesuatu dengan inovasi baru yang menarik dan memiliki imajinasi yang tinggi.

3. Collaboration

Peserta didik akan terlibat aktif dalam proses pembelajaran jika terlibat dalam kelompok-kelompok kecil dibandingan hanya mendengarkan penjelasan/ceramah dari guru (Warsono \& Hariyant0, 2012). Oleh karena itu, keterampilan kolaboratif dapat diartikan sebagai suatu keterampilan yang melibatkan anak didik untuk berdiskusi dalam suatu kelompok sehingga terbangun pengetahuan dan tercapainya tujuan pembelajaran bersama melalui interaksi social di bawah bimbingan dari pendidik (Septikasari \& Frasandy, 2018)

4. Communication

Komunikasi dalam konteks abad ke-21 merujuk tidak hanya untuk kemampuan berkomunikasi secara efektif, secara lisan dan tulisan, dan dengan berbagai alat digital, tetapi juga keterampilan mendengarkan (Fullan, 2013). Oleh karena itu, implementasi keterampilan komunikasi pada proses pembelajaran yakni peserta didik melakukan presentasi hasil diskusinya dihadapan guru dan teman lain baik secara tatap muka maupun tatap maya. Setelah itu, teman lainnya memberikan tanggapan terkait hasil presentasi. Sehingga terjadi komunikasi dua arah yang melibatkan anak didik maupun pendidik.

Pada proses perencanaan pembelajaran yang dilakukanoleh guru, keterampilan 4C dapat digunakan dan dipetakan dalam perencanaan pembelajaran. Berikut contoh yang dapat dijabarkan dari persiapan pembelajaran pada tabel 1 di bawah ini: 
Volume 9 Nomor 1 Tahun 2021

Tabel 1. Implementasi Keterampilan 4C pada

\begin{tabular}{|c|c|}
\hline Tema & Kompetensi Dasar \\
\hline Tema 8, & BAHASA INDONESIA \\
\hline \multirow[t]{4}{*}{$\begin{array}{l}\text { Subtema 1, } \\
\text { Pembelajaran } 2\end{array}$} & $\begin{array}{l}\text { 3.9 Mencermati tokoh-tokoh yang terdapat pada } \\
\text { teks fiksi }\end{array}$ \\
\hline & IPA \\
\hline & $\begin{array}{l}\text { 3.4 Menghubungkan gaya dengan gerak pada } \\
\text { peristiwa di lingkungan sekitar } \\
\text { SBDP }\end{array}$ \\
\hline & $\begin{array}{l}\text { 3.2 Mengetahui tanda tempo dan tinggi rendah } \\
\text { nada }\end{array}$ \\
\hline Keterampilan $4 \mathrm{C}$ & Tujuan Pembelajaran \\
\hline Critical Thinking & $\begin{array}{l}\text { Melalui percobaan, peserta didik dapat } \\
\text { menyimpulkan hasil analisis tentang hubungan } \\
\text { gaya dan arah gerak suatu benda dengan tepat. }\end{array}$ \\
\hline Creative Thinking & $\begin{array}{l}\text { Melalui penugasan, peserta didik dapat } \\
\text { mempraktikan lagu "Cublak-Cublak Suweng" } \\
\text { memakai pakaian adat sesuai kreativitas sendiri } \\
\text { dengan percaya diri. }\end{array}$ \\
\hline Collaboration & $\begin{array}{l}\text { Melalui kegiatan diskusi pada WA group, peserta } \\
\text { didik dapat mengidentifikasi tokoh-tokoh yang ada } \\
\text { pada cerita dengan tepat. }\end{array}$ \\
\hline Communication & $\begin{array}{l}\text { Melalui kegiatan google meeting, peserta didik } \\
\text { dapat mempresentasikan hasil diskusi dengan } \\
\text { percaya diri. }\end{array}$ \\
\hline
\end{tabular}

B. HOTS (Higher Order Thinking Skill)

HOTS merupakan suatu keterampilan berpikir tingkat tinggi merupakan suatu keterampilan berpkiri tingkat tinggi merupakan suatu proses berpikir kompleks dalam menguraikan materi, membuat kesimpulan, membangun representasi, menganalisis, dan membangun hubungan dengan melibatkan aktivitas mental yang paling dasar (Resnick dalam Mustaghfirin, 2019). Pembelajaran HOTS berbeda dengan pembelajaran berbasis LOTS. Menurut pendapat Sani, (2019) perbedaan antara aktivitas belajar antara LOTS dan HOTS dapat dilihat pada tabel 2 di bawah ini:

Tabel 2. Perbedaan Aktivitas Belajar LOTS dan HOTS

\begin{tabular}{|c|c|c|}
\hline No. & LOTS & HOTS \\
\hline 1 & Pasif dalam berpikir & Aktif dalam berpikir \\
\hline 2 & Menyelesaikan masalah & Memformulasikan masalah \\
\hline 3 & Mengkaji permasalahan sederhana & $\begin{array}{l}\text { Mengkaji permasalahan } \\
\text { kompleks }\end{array}$ \\
\hline 4 & Berpikir konvergen & $\begin{array}{l}\text { Berpikir divergen dan } \\
\text { mengembangkan ide }\end{array}$ \\
\hline 5 & $\begin{array}{l}\text { Belajar dari guru sebagai sumber } \\
\text { informasi utama }\end{array}$ & $\begin{array}{l}\text { Mencari informasi dari } \\
\text { berbagai sumber }\end{array}$ \\
\hline 6 & $\begin{array}{l}\text { Berlatih menyelesaikan soal dan } \\
\text { menghafal }\end{array}$ & $\begin{array}{l}\text { berpikir kritis dan } \\
\text { menyelasaikan masalah } \\
\text { secara kreatif }\end{array}$ \\
\hline 7 & Mengutamakan pengetahuan faktual & $\begin{array}{l}\text { Berpikir analitik, evaluatif, dan } \\
\text { membuat kesimpulan }\end{array}$ \\
\hline
\end{tabular}




\section{SIMPULAN}

Merujuk pada latar belakang masalah pada pendahuluan dan pembahasan dapat disimpulkan bahwa keterampilan yang ada pada abad 21 dibedakan menjadi empat atau dikenal dengan sebutan 4C (Critical Thinking and Problem Solving, Creative Thinking and Innovation, Collaboration, Communicatin). Keterampilan berpikir kritis dapat diimplementasikan pada pembelajaran berbasis HOTS. Pembelajaran ini menuntut peserta didik untuk lebih berpikir tingkat tinggi saat menyelesaikan suatu permasalahan. Meskipun di masa pandemi, guru senantiasa mengemas pembelajaran sedemikian rupa dengan menerapkan keterampilan 4C dan berbasis HOTS dengan bantuan aplikasi digital selama pembelajaran daring.

\section{DAFTAR PUSTAKA}

Eggen, P \& Kauchack, D. (2012). Strategi dan Model Pembelajaran, Mengajarkan Konten dan Keterampilan Berpikir Edisi 6. Jakarta: Indeks

Ferdinandus, B., S., \& Desak, M., A. (2018). Inovasi Pembelajaran Elektronik dan Tantangan Guru Abad 21. Jurnal Penelitian dan Pengkajian IImu Pengetahuan: E-Saintika, 2(1), 10-18

Fullan, M. (2013). Great to excellent: Launching the next stage of Ontario's education agenda. Toronto: Ontario Ministry of Education. Retrieved from: www.edu.gov.on.ca/eng/ document/reports/FullanReport_EN_07.pdf

Halpern, D.F. (2014). Thought and Knowledge: an introduction to critical thinking. New York: Taylor and Francis

Mustaghfirin Amin. (2019). Penyusunan Instrumen Penilaian Berbasis Hots. Handout Makalah. Jakarta: Kementerian Pendidikan Dan Kebudayaan Direktorat Jenderal Pendidikan Dasar Dan Menengah Direktorat Pembinaan Sekolah Menengah Kejuruan

Rusman. (2013). Metode-Metode Pembelajaran: Mengembangkan Profesionalisme Guru. Jakarta: PT Raja Grafindo Persada

Sani, R.A. (2019). Pembelajaran Berbasis HOTS (High Order Thinking Skill). Tangerang: Tsmart Printing

Septikasari, R. \& Frasandy, R. N. (2018). Keterampilan 4C Abad 21 dalam Pembelajaran Pendidikan Dasar. Jurnal Tarbiyah Al-Awlad. 8(2), 112-122

Supardi, U.S. (2015). Arah Pendidikan di Indonesia dalam Tataran Kebijakan dan Implementasi. Jurnal Formatif, 2(2), 111-121

Trisiana, A. (2020). Digital Media-Based Character Education Model As A Learning Innovation In The Model Of A Corona Pandemic). Webology. Vol: 17 (2). Pp.103117

Warsono \& Hariyanto. (2012). Pembelajaran Aktif: Teori dan Asesmen. Bandung: Remadja Rosdakarya 